\title{
Effect of fertilisation and drainage intensity on the foliar radiocaesium and potassium concentrations of Scots pine on a drained peatland
}

\author{
S. Kaunisto, L. Aro and A. Rantavaara ${ }^{1}$ \\ Finnish Forest Research Institute, METLA, Parkano Research Station, 39700 Parkano, Finland \\ ${ }^{1}$ Radiation and Nuclear Safety Authority, STUK, P.O. Box 14, 00881 Helsinki, Finiand
}

\begin{abstract}
This study aims at finding out the effects of fertilisation and drainage intensity on the needle ${ }^{14} \mathrm{Cs}$ and ${ }^{137} \mathrm{Cs}$ activity in Pinus sy/vestris on a pine mire in Finland. The fertilisation treatments were as follows: a control, fertilised once in 1965 or fertilised twice in 1965 and 1977, with $\mathrm{N}, \mathrm{P}$ and $\mathrm{K}$. The potassium concentrations of the

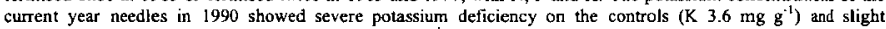
deficiency on the plots fertilised only once ( $\mathrm{K} 4.2 \mathrm{mg} \mathrm{g}^{-1}$ ) but no deficiency on the plots fertilised twice (K $4.8 \mathrm{mg}$ $\left.\mathrm{g}^{-1}\right)$. Fertilisation decreased the radiocaesium concentrations and amounts in the needles. The concentrations of ${ }^{14} \mathrm{Cs}$ were 821 in the control, 442 in the single fertilisation and $485 \mathrm{~Bq} \mathrm{~kg}^{-1}$ in the repeated fertilisation treatment, and the ${ }^{137} \mathrm{Cs}$ concentrations 5378,2734 and $2104 \mathrm{~Bq} \mathrm{~kg}$, respectively. Drainage intensity $(10.100 \mathrm{~m})$ had no significant effect on the needle $\mathrm{K}$ concentration or radjocaesium activity.
\end{abstract}

\section{INTRODUCTION}

Peatlands suitable for growing forests have adequate nitrogen status but often only limited amounts of mineral nutrients in Finnish conditions. Potassium is often a growth-limiting nutrient especially on originally wet and sparsely stocked peatlands [1]. Tree roots penetrate seldom deeper than $20 \mathrm{~cm}$ even into drained peat soils [2]. This, $0-20 \mathrm{~cm}$, peat layer may contain as much as $[3,4]$ but often less potassium than a tree stand of $150 \mathrm{~m}^{3}$ [5]. Some investigations have shown that potassium deficiency enhances ${ }^{137} \mathrm{Cs}$ uptake by trees and that potassium fertilisation decreases it in adequate drainage conditions used also in forestry practice $[6,7]$. It is not known if this is true also in more intensive or less intensive drainage conditions.

This study aims at finding out the effect of potassium fertilisation on the needle ${ }^{137} \mathrm{Cs}$ and potassium concentrations of Scots pine on a pine mire in a wider range of drainage conditions than used in forestry practice.

\section{MATERIAL AND METHODS}

\subsection{Site and treatments}

The material was collected from a ditch spacing and fertilisation experiment in western Finland $\left(61^{\circ} 59^{\prime} \mathrm{N}, 23^{\circ} 15^{\circ} \mathrm{E} ;[8,9]\right)$. The experiment was established in the middle of the $1950^{\prime} \mathrm{s}$. The peatland site type was originally a low/tall sedge pine mire, presently stocked by uneven-aged, 50-80-year-old Scots pines and downy birches. Scots pine was the dominating tree species. Nitrogen concentrations in peat varied between 1.7 and $2.3 \%$, phosphorus concentrations between 863 and $1281 \mathrm{mg} \mathrm{kg}^{-1}$, and potassium concentrations between 144 and $451 \mathrm{mg} \mathrm{kg}^{-1}$ in the 0 and $10 \mathrm{~cm}$ surface peat layer. The lowest potassium concentrations were in the unfertilised treatments. The peat layer was more than one meter thick in the whole area.

Partly the same fertilisation treatments as in the study by Kaunisto et al. [7] but instead of three six ditch spacing treatments were selected for this study. The fertilisation treatments were as follows: a control, single fertilisation with PK or NPK in 1965, and fertilisation with PK or NPK in 1965 and with NPK in 1977. In $196536 \mathrm{~kg}$ of $P$ and $69 \mathrm{~kg}$ of K or $50 \mathrm{~kg}$ of $\mathrm{N}, 26 \mathrm{~kg}$ of $P$ and $25 \mathrm{~kg}$ of K ha $\mathrm{K}^{-1}$ were given as broadcast fertilisation. In 1977 the amounts of elements were $110 \mathrm{~kg}$ of N, $42 \mathrm{~kg}$ of $P$ and $79 \mathrm{~kg}$ $\mathrm{ha}^{-1}$ of $\mathrm{K}$. The total phosphorus and potassium application rates were low in 1965 compared with the present practice (about $45 \mathrm{~kg} \mathrm{ha}{ }^{-1}$ of $\mathrm{P}$ and $80 \mathrm{~kg} \mathrm{ha}^{-1}$ of $\mathrm{K}$ ). Potassium was given as $\mathrm{KCl}$. The ditch spacing treatments were $10,20,40,60,80$ and $100 \mathrm{~m}$. 


\subsection{Needle sampling and analyses}

Current year needles (1989) were collected from 10 trees in each plot and combined in February 1990. Needles were sampled from two uppermost whorls of each sample tree.

Radiocaesium in dried, homogenised samples was determined with a low-background highresolution (HPGe) gammaspectrometer at the radioanalytical laboratory of STUK. The reference date for radiocaesium concentrations was $\mathrm{xx}$ of February 1990/5?. Needle potassium was analysed by atomic absorption spectrophotometer after dry combustion and $\mathrm{HCl}$ extraction at the laboratory of Parkano Research Station [10]. Analysis of variance for the split plot design (BMDP software package) ws used for calculations.

\section{RESULTS AND DISCUSSION}

The needle $\mathrm{K}$ concentrations for the control varied between 2.6 and $4.0 \mathrm{mg} \mathrm{g}^{-1}$ (mean 3.6 ), for trees fertilised only once between 3.8 and $4.9 \mathrm{mg} \mathrm{g}^{-1}$ (mean 4.2) and for refertilised trees between 3.9 and 5.2 $\mathrm{mg} \mathrm{g}^{-1}$ (mean 4.8, Fig. 1). On average, the $\mathrm{K}$ concentrations were near or under the severe potassium deficiency limit $\left(3.5 \mathrm{mg} \mathrm{g} \mathrm{g}^{-1},[11,12]\right)$ on the unfertilised plots but well above the slight potassium deficiency level $\left(4.0 \mathrm{mg} \mathrm{g} \mathrm{g}^{-1},[11]\right)$ in the needles of the refertilised trees. The mean needle $K$ concentration of trees fertilised only once was between these two. The difference between the control trees and the fertilised ones was statistically significant $(p<0.00 \mathrm{l}$, Table 1$)$. Fertilisation increased also the amount of potassium in 100 needles significantly ( $p<0.0001$, Tables 1 and 2 ). Usually, the effect of potassium fertilisation on the needle potassium concentrations lasts for less than twenty years when using potassium chloride [13]. The concentrations were near the deficiency limit also in the fertilised and refertilised trees on the most intensively drained sites but adequate on the 40 -meter or wider strips. This may be due to a higher potassium requirement in good drainage conditions. However, the difference in the needle potassium concentrations or potassium amounts in 100 needles was not significant between different ditch spacings (Table 1).

${ }^{137} \mathrm{Cs}$ concentrations in the needles varied between 4277 and $6620 \mathrm{~Bq} \mathrm{~kg}^{-1}$ in the control trees (mean 5378), 2065 and $4227 \mathrm{~Bq} \mathrm{~kg}^{-1}$ in the fertilised ones (mean 2734) and 1541 and $3007 \mathrm{~Bq} \mathrm{~kg}^{-1}$ in the refertilised ones (mean 2104, Fig. 1). Fertilisation decreased both the concentrations and amounts in 100 needles of ${ }^{137} \mathrm{Cs}$ significantly $(\mathrm{p}<0.0001)$ but only a little more effectively in the refertilised trees than in trees fertilised only once (Fig. 1, Tables 1 and 2). This agrees well with the results by Moberg et al. [6] and Kaunisto et al. [7]. Drainage intensity did not have a significant effect on the ${ }^{137} \mathrm{Cs}$ concentrations or amounts in 100 needles (Tables 1 and 2).

\section{CONCLUSION}

Needle analysis seems to be a fairly good indicator of ${ }^{137} \mathrm{Cs}$ uptake by trees. Fertilisation with potassium containing fertilisers considerably decreases radiocaesium uptake by trees. It seems that fertilisation with potassium has a long lasting repulsive effect on the ${ }^{137} \mathrm{Cs}$ uptake in a very wide range of drainage conditions. Drainage intensities practised in forestry seem not to affect ${ }^{137} \mathrm{Cs}$ uptake by trees. 


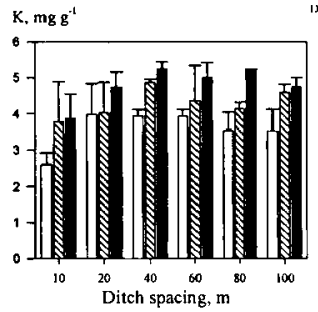

${ }^{13} \mathrm{Cs}, \mathrm{Bq} \mathrm{kg}{ }^{-1}$

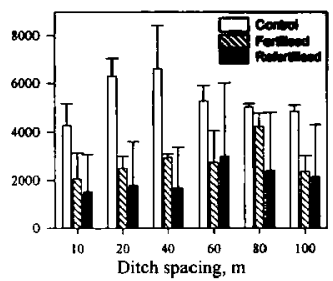

Flgure 1: Effect of fertilisation and drainage intensity on the ${ }^{137} \mathrm{Cs}$ and potassium concentrations in Scots pine needles. SD is marked on the top of bars.

Tabie 1: Effect of fertilisation and drainage intensity (ditch spacing) on the ${ }^{137} \mathrm{Cs}$ and potassium concentrations and amounts in Scots pine reedles: results of the ANOVA.

\begin{tabular}{|c|c|c|c|c|}
\hline Variable & Source & d.f. & F value & $P$ value \\
\hline \multirow[t]{2}{*}{${ }^{137} \mathrm{Cs}, \mathrm{Bq} \mathrm{kg}{ }^{-1}$} & ditch spacing & 5 & 1.63 & 0.247 \\
\hline & $\begin{array}{l}\text { fertilisation } \\
d * f\end{array}$ & $\begin{array}{r}2 \\
10\end{array}$ & $\begin{array}{r}75.71 \\
2.04\end{array}$ & $\begin{array}{l}0.000 \\
0.091\end{array}$ \\
\hline $\mathbf{K}, \mathrm{mg} \mathrm{g}^{-1}$ & $\begin{array}{l}\text { ditch spacing } \\
\text { fertilisation } \\
d^{*} f\end{array}$ & $\begin{array}{r}5 \\
2 \\
10\end{array}$ & $\begin{array}{r}3.10 \\
16.88 \\
0.56\end{array}$ & $\begin{array}{l}0.067 \\
0.000 \\
0.824\end{array}$ \\
\hline $\begin{array}{l}\text { Dry weight of } \\
100 \text { needles, } g\end{array}$ & $\begin{array}{l}\text { ditch spacing } \\
\text { ferilisation } \\
d^{*} \mathbf{f}\end{array}$ & $\begin{array}{r}5 \\
2 \\
10\end{array}$ & $\begin{array}{l}0.20 \\
3.37 \\
0.79\end{array}$ & $\begin{array}{l}0.953 \\
0.057 \\
0.641\end{array}$ \\
\hline \multirow[t]{2}{*}{${ }^{137} \mathrm{Cs}, \mathrm{Bq}$ in 100 needles } & ditch spacing & 5 & 0.73 & 0.619 \\
\hline & $\begin{array}{l}\text { fertilisation } \\
d * f\end{array}$ & $\begin{array}{r}2 \\
10\end{array}$ & $\begin{array}{r}29.00 \\
1.82\end{array}$ & $\begin{array}{l}0.000 \\
0.129\end{array}$ \\
\hline $\mathrm{K}$, mg in 100 needles & $\begin{array}{l}\text { ditch spacing } \\
\text { fertilisation } \\
d^{*} \mathbf{f}\end{array}$ & $\begin{array}{r}5 \\
2 \\
10\end{array}$ & $\begin{array}{l}0.58 \\
8.57 \\
0.48\end{array}$ & $\begin{array}{l}0.716 \\
0.002 \\
0.880\end{array}$ \\
\hline
\end{tabular}


Table 2: Mean values ( \pm SD) of dry weight, potassium and ${ }^{137} \mathrm{Cs}$ amounts in 100 needles in different fertilisation and drainage intensity (ditch spacing) treatments.

\begin{tabular}{|c|c|c|c|c|}
\hline Fertilisation & $\begin{array}{c}\text { Ditch } \\
\text { spacing, an }\end{array}$ & Dry weight, $\mathrm{g}$ & $\mathbf{K}, \mathbf{m g}$ & ${ }^{137} \mathrm{Cs}, \mathrm{Bq}$ \\
\hline \multirow[t]{6}{*}{ Control } & 10 & $1.39 \pm 0.13$ & $3.60 \pm 0.42$ & $5.91 \pm 1.15$ \\
\hline & 20 & $1.23 \pm 0.05$ & $4.94 \pm 1.28$ & $7.74 \pm 0.72$ \\
\hline & 4 & $1.55 \pm 0.47$ & $6.03 \pm 1.58$ & $10.66 \pm 5.94$ \\
\hline & 6 & $1.35 \pm 0.15$ & $5.25 \pm 0.33$ & $7.16 \pm 1.49$ \\
\hline & 6 & $1.20 \pm 0.04$ & $4.22 \pm 0.47$ & $6.03 \pm 0.32$ \\
\hline & 100 & $1.15 \pm 0.07$ & $4.07 \pm 0.94$ & $5.60 \pm 0.05$ \\
\hline \multirow[t]{6}{*}{ Single fertilisation } & 10 & $1.61 \pm 0.24$ & $6.18 \pm 2.42$ & $3.33 \pm 1.83$ \\
\hline & 20 & $1.79 \pm 0.28$ & $7.29 \pm 2.26$ & $4.38 \pm 0.19$ \\
\hline & 40 & $1.22 \pm 0.23$ & $5.91 \pm 1.03$ & $3.61 \pm 0.85$ \\
\hline & 60 & $1.73 \pm 0.38$ & $7.71=3.26$ & $4.62 \pm 2.21$ \\
\hline & 80 & $1.50 \pm 0.21$ & $6.21 \pm 1.12$ & $6.39 \pm 1.71$ \\
\hline & 100 & $1.87 \pm 0.85$ & $8.67 \pm 4.29$ & $4.14 \pm 0.77$ \\
\hline \multirow[t]{6}{*}{ Repeated fertilisation } & 10 & $1.38 \pm 0.64$ & $5.55 \pm 3.28$ & $2.10 \pm 1.02$ \\
\hline & 20 & $1.53 \pm 0.04$ & $7.23 \pm 0.46$ & $2.74 \pm 1.12$ \\
\hline & 40 & $1.56 \pm 0.13$ & $8.16 \pm 0.34$ & $2.66 \pm 0.87$ \\
\hline & 60 & $1.40 \pm 0.24$ & $7.02 \pm 1.28$ & $4.09 \pm 1.16$ \\
\hline & 80 & $1.36 \pm 0.66$ & $7.09 \pm 3.44$ & $3.69 \pm 3.27$ \\
\hline & 100 & $1.57 \pm 0.04$ & $7.40 \pm 0.22$ & $3.38 \pm 1.51$ \\
\hline
\end{tabular}

\section{Acknowledgments}

The English was revised by Leena Kaunisto.

\section{References}

[1] Kaunisto S. Suo 43 (1992) 45-62.

[2] Paavilainen E. Commun. Inst. For. Fenn. 61.1 (1966) 110 p.

[3] Laiho R. and Laine J. Scand. J. For. Res. 10 (1995) 218-224.

[4] Kaunisto S. and Moilanen M. Metsätieteen aikakauskirja - Folia Forestalia 3/1998 (1998) 393-4l0.

[5] Kaunisto S. and Paavilainen E. Commun. Inst. For. Fenn. 145 (1988) 1-39.

[6] Moberg L. Hubbard L., Avila R., Wallberg L., Feoli E., Scimone M., Milesi C., Mayes B., Iason G., Rantavaara A., Vetikko V., Bergman R., Nylén T., Palo T., White N., Raitio H., Aro L., Kaunisto S. and Guillitte $O$. An Integrated Approach to Radionuclide Flow in Semi-natural Ecosystems Underlying Exposure Pathways to Man. Final Report of the LANDSCAPE Project (Swedish Radiation Protection Institute, Stockholm, 1999) 104 p.

[7] Kaunisto S., Aro L. and Rantavaara A. Env. Pollution In print (2001) 9 p. (TARK LYHENNE)

[8] Huikari O. Commun. Inst. For. Fenn. 51.2 (1959) 1-45.

[9] Ahti E. Commun. Inst. For. Fenn. 111 (1983) 1-20.

[10] Halonen O., Tulkki H. and Derome J. Finnish For. Res. Inst., Res. papers 121 (1983) 1-28.

[11] Paarlahti K., Reinikainen A. \& Veijalainen H. Commun. Inst. For. Fenn. 74.5 (1971) 58 p.

[12] Sarjala T. \& Kaunisto S. Tree Phys 13 (1993) 87-96.

[13] Kaunisto S., Moilanen M. and Issakainen J. Suo 50 (1999) 1-15. 